\title{
Additive Manufacturing Technologies Used for 3D Metal Printing in Dentistry
}

\author{
Revilla-León, Marta ; Ȯzcan, Mutlu
}

\begin{abstract}
Purpose of ReviewCompared to conventional casting methods used for processing different alloys for dental applications, additive manufacturing technologies reduce manufacturing time and costs, minimize human errors and prevent possible defects in the cast objects. This review highlights working mechanisms, possible advantages and drawbacks of recent additive manufacturing technologies used for metal processing in dentistry. Recent FindingsThe literature reviewed indicated that powder-based fusion mainly based on selective laser sintering, selective laser melting and electro beam melting are the most commonly used technologies for 3D metal printing in dentistry for dental appliances made of $\mathrm{CoCr}$ and Ti6Al4V. Although mechanical properties of 3D printed alloys could be considered satisfactory, accuracy and reproducibility data do not present consistent results. SummaryThere appears room for improvement between 3D printed metals and ceramic interfaces and precision before such technologies could be favoured over conventional cast methods.
\end{abstract}

DOI: https://doi.org/10.1007/s40496-017-0152-0

Posted at the Zurich Open Repository and Archive, University of Zurich

ZORA URL: https://doi.org/10.5167/uzh-146617

Journal Article

Accepted Version

Originally published at:

Revilla-León, Marta; Ȯzcan, Mutlu (2017). Additive Manufacturing Technologies Used for 3D Metal Printing in Dentistry. Current Oral Health Reports, 4(3):201-208.

DOI: https://doi.org/10.1007/s40496-017-0152-0 


\section{Additive Manufacturing Technologies Used for 3D Metal Printing in Dentistry}

Marta Revilla-León ${ }^{1} \bullet$ Mutlu Özcan²

${ }^{1}$ Private practice, Madrid, Spain and Affiliate Faculty Graduate of Department of Prosthodontics, University of Washington, Seattle, USA

${ }^{2}$ University of Zurich, Division of Dental Materials, Center for Dental and Oral Medicine, Clinic for Fixed and Removable Prosthodontics and Dental Materials Science, Zurich, Switzerland

M. Revilla León*

Revilla Research Center, Calle Berlin 14, 28922 Madrid, Spain

E-mail: revilla@revillaresearchcenter.com 


\begin{abstract}
Purpose of Review: Compared to conventional casting methods used for processing different alloys for dental applications, additive manufacturing technologies reduce manufacturing time and costs, minimize human errors and prevent possible defects in the cast objects. This review highlights working mechanisms, possible advantages and drawbacks of recent additive manufacturing technologies used for metal processing in dentistry. Recent Findings: The literature reviewed indicated that powder based fusion mainly based on selective laser sintering, selective laser melting and electro beam melting are the most commonly used technologies for 3D metal printing in dentistry for dental appliances made of CoCr and Ti6Al4V. Although mechanical properties of 3D printed alloys could be considered satisfactory, accuracy and reproducibility data do not present consistent results. Summary: There appears room for improvement between 3D printed metals and ceramic interfaces and precision before such technologies could be favoured over conventional cast methods.
\end{abstract}

Keywords 3D printing • Additive Manufacturing • Electron Beam Melting • Metal • Prosthodontics • Selective Laser Sintering • Selective Laser Melting 


\section{Introduction}

Technologies based on Computer Aided Design and Computer Aided Manufacturing (CADCAM) typically comprise three fundamental elements embedded in the digital workflow: (1) data acquisition or digitizing, (2) data processing (CAD) and (3) manufacturing (CAM) [1]. The most commonly used CAM process today is the computer numerically controlled (CNC) machining that is based on routes where power-driven machinery tools, such as saws, lathes, milling machines, and sharp cutting drills or tools that mechanically cut the material to achieve the desired geometry with all the steps controlled by a computer program [2-4]. However, such technologies present a number of manufacturing limitations, namely, a considerable amount of raw material is wasted as unused parts of the milled blocks, the milling tools needs to be replaced after a short number of running cycles due to the heavy abrasion and wear when milling and the size of the milling burs and the axis of the CNC machine may limit the access to the small areas of the block to be milled [5-8].

As an alternative to the subtractive methods, additive processes provide manufacturing procedures in which the powder or liquid base material is build into a solid object $[9,10]$. The American Society for Testing and Materials (ASTM) has defined Additive Manufacturing (AM) as "a process of joining materials to make objects from 3D model data, usually layer upon layer, as opposed to subtractive manufacturing methodologies" [11]. The CAD data files exported for the industry-standard exchange file format is the Standard Triangulation Language (STL) that is a boundary representation consisting a list of triangular facets [12]. In 2008, the ASTM international committee F42 on AM technologies has classified seven 
categories: stereolithography (SLA), material jetting (MJ), material extrusion (ME), binder jetting (BJ), powder based fusion (PBF), sheet lamination (SL) and direct energy deposition (DEP) [11].

\section{Powder based fusion technologies}

Powder based fusion (PBF) is the most commonly used technology for 3D metal printing in dentistry. Currently, three types of PBF technologies are available, namely selective laser sintering (SLS), selective laser melting (SLM) and electro beam melting (EBM) $[9,11]$ :

\section{Selective Laser Sintering (SLS)}

Selective Laser Sintering (SLS) technology was developed by Carl Deckard and Joe Beaman and patented in $1989[13,14]$ that is based on application of high powered laser (Na:YAG laser) beam focused onto a bed of powdered metal where thin solid layers (20$100 \mu \mathrm{m})$ are fused until the 3-dimensional (3D) object is built [15]. The entire fabrication chamber is sealed and maintained at a temperature just below the melting point that the metal powder sinters [16]. Object parts made by partial melting are characterized by high porosity with initially achieving only point contacts between the particles. During laser heating, various sintering and rearrangement mechanisms induce the powder binding and densification. Unfortunately, with partial melting and sintering mechanism, porosities could not be complete eliminated as generally possible repulsion forces arise between particles at a high fraction of the binding liquid component [17]. 


\section{Selective Laser Melting (SLM)}

With the introduction of powerful high-quality lasers, the partial melting achieved by SLS technology has been taken over by complete melting, giving rise to a new development of metal laser sintering (MLS) or SLM [18-21]. Although the superficial finish is considered very well, the components may have high internal stresses caused by thermal gradients induced during processing and therefore require additional heat treatment [20]. The most common fibre laser used on the SLM technology is the $\mathrm{CO}_{2}$ laser $(1-2 \mathrm{~kW})$ for processing metal powders and the building plate can be preheated up to $200^{\circ} \mathrm{C}$ [21].

\section{Electron Beam Melting (EBM)}

Instead of using a laser beam $(60 \mathrm{~kW})$ to melt or sinter the powder, with the EBM technologies, a focused electron beam is used to selectively melt layers of powder $(100 \mu \mathrm{m})$ in an inert environment such as purified argon. Also, while building the part, an elevated temperature of about $700^{\circ} \mathrm{C}$ is maintained in the chamber to reduce the residual stresses. Initially, a tungsten filament is heated over $3000^{\circ} \mathrm{C}$, which causes electrons to be emitted, and subsequently, potential difference between a cathode and an anode causes the electrons to accelerate. The electrons are focused and detected using magnetic coils to form a narrow high-energy beam that attacks the surface of the powder. Eventually, the kinetic energy transferred through friction creates the heat that is necessary to melt the metal powder [19,22].

The main differences between the PBF technologies are the operational parameters such as melting temperature, energy source, energy power, laser beam absorption/reflections coefficients, thermal conductivity, chamber conditions, temperature reached, along with 
other parameters such layer thickness, build orientation and grain size [23-25]. All these parameters have to be adjusted depending on the metal type.

Representative examples of implant frameworks using SLM technology is presented in Figs. 1a-d.

\section{Metals used in additive manufacturing in dentistry}

For 3D metal printing in dental applications, currently Cobalt-Chrome (Co-Cr) and Titanium (Ti) are the most commonly used alloys.

The metal powder of Co-Cr also contains Molybdenum, Tungsten, Silicon, Cerium, Iron, Manganese and Carbon, while Nickel and Beryllium are not present in the composition anymore. The metal powders used in conjunction with AM technologies are a mixture of particles with sizes ranging between 3 and $14 \mu \mathrm{m}[25,26]$. Depending on the manufacturers of the AM technologies, composition (Table 1) and mechanical properties of Co-Cr may show differences between products (Table 2). Likewise, typical titanium alloys used in dentistry and medicine such as Ti6Al4V show slight differences in composition (Table 3) and physical and mechanical properties depending on the AM system (i.e. SLM vs. EBM) (Table 4) [27-30].

\section{Mechanical properties of 3D printed metals}

The recommended mechanical properties for the $\mathrm{CoCr}$ alloys for fixed and removable dental restorations and appliances are reflected in the ISO 22674 [31]. Few studies compared the mechanical properties of cast, milled and AM alloys used for dental purposes [32-34]. In 2014, Al Jabbari et al [32] evaluated the hardness and microstructural characterization of 
the $\mathrm{CoCr}$ dental alloys manufactured using casting, milling or SLM techniques where significant differences were noted in hardness values being the highest for SLM $(371 \pm 10$ $\mathrm{HV})$, followed by the cast $(320 \pm 12 \mathrm{HV})$ and milled $(297 \pm 5 \mathrm{HV})$ procedures. The manufacturing process showed also a significant effect on the alloy microstructure where Xray radiography revealed the presence of porosity only in the cast group. It has to be noted that, although effort was made to use one type of $\mathrm{CoCr}$ alloy for all procedures, for SLM manufacturing another type of $\mathrm{CoCr}$ alloy had to be used which has slightly higher $\mathrm{Co} / \mathrm{Cr}$ ratio than those of cast and milled ones. Building direction and tensile directions $(0,45$ and $90^{\circ}$ ) also significantly affected the mechanical properties of CoCr SLM specimens [35] where zero angle build up (building and tensile direction are parallel) demonstrated the highest tensile strengths and elongation after fracture.

The objects made of CoCr through the SLS or SLM technologies present thermal stresses in the body of the object due to rapid heating and cooling during the fabrication process [35]. Such internal residual stress could generate high strain and thereby affects the accuracy $[36,37]$. One solution to circumvent this problem is the employment of heat treatment after printing the metal that could at the same time change the micro-structure $[34,38]$. Nevertheless, the reduction in porosity in CoCr alloys fabricated through AM technologies, has a positive effect on the mechanical properties of the printed object [34] through which higher yield and tensile strength of the cast alloys could be obtained [39]. Corrosion resistance of CoCr SLM specimens on the other hand, appears to remain similar to that of the conventional casting processing [40-42].

Ti6Al4V is a two-phase material, consisting of the hexagonal close packed (hcp) a phase and the body center cubic (bcc) $\beta$ phase [43]. The transition temperature between the two 
phases for Ti6Al4V is $995^{\circ} \mathrm{C}$ [44,45]. The mechanical properties of the two-phase Ti6Al4V alloy are dependent on the microstructure and the distribution of the two phases throughout the material $[44,46,47]$. The SLM technology is more commonly used to manufacture Ti6Al4V fixed dental prostheses (FDPs) than EBM. SLM produces more rapid cooling, resulting in transformation to a'martensite phase in various proportions that significantly affects the corrosion potential and be detrimental for dental applications [43]. However, when low oxygen containing powder is used in EBM fabrication, mechanical properties could be improved. [30]. Mechanical properties of the Ti6Al4V alloy fabricated using EBM versus casting was reported to deliver strength $(1.18 \mathrm{GPa})$ and elongation (16 to $25 \%)$ with microindentation hardness ranging from 3.6 to $3.9 \mathrm{GPa}$, comparable to the very best wrought Ti6Al4V alloy (4 GPa) [43].

Compared to conventional casting method, AM technologies offer the advantages of high product density, reduced manufacturing time and costs, minimization of human errors, and the prevention of casting defects. However, different dental applications would necessitate some prerequisites from AM technologies for optimum outcome.

\section{Dental applications using additive technologies}

\section{Removable Partial Dentures (RPD) and overdentures}

In 2004, Williams et al [48] described digital surveying a definitive cast, CAD design and SLA AM resin pattern fabrication for casting the RPD metal frameworks. Subsequently, in 2006, Williams et al $[49,50]$ developed the technique for the Co-Cr SLM AM technology to manufacture RPD frameworks. Thereafter, Kattadiyil et al [51] closed the digital workflow incorporating the intraoral digital impression (Cadent Itero, San Jose, CA, USA) of the 
partially edentulous maxillary arch (Kennedy Class III) for the fabrication of an RPD. The case report described the digital impression where 28 scans were needed for the maxillary teeth and occlusion, 25 scans to enhance the capture of the rest seats and 28 scans for the mandibular teeth yielding to a total of 17 minutes. This remained a major drawback until 2014 when Kanazawa et al, reported a protocol for Ti6Al4V framework for a complete maxillary denture using the SLM technology, with a layer thickness of $30 \mu \mathrm{m}$ [52]. The digitalization of the definitive plaster cast was executed with a 3D cone-beam computed tomography and the digital design was completed with a non-dental CAD software (Freeform, Geomatic) which made the whole process much more practical [53]. In 2016, Lee et al [54] measured the internal fit of 10 RPDs made for 10 patients using SLM technology. Although no significant differences were found among participants in terms of internal discrepancy of the various framework components, unfortunately the results were not compared to the conventionally fabricated RPDs. Likewise, technique description for a SLM CoCr superstructure framework of a maxillary implant-retained overdenture is available but systematic measurements are lacking [55-62]. AM technologies could be also used to manufacture implant-borne fixed prostheses but due to the roughness and texture of the metals, this technology still needs to be combined with subtractive technologies.

\section{Fixed Dental Prostheses (FDP)}

AM technologies were also introduced for the fabrication of $\mathrm{CoCr}$ alloy frameworks for crowns and FDPs but the major focus of research is on precision and ceramic adhesion that are critical for the longevity of such reconstructions. 


\section{Marginal and internal gap}

Marginal and internal gap of $\mathrm{CoCr}$ 3-unit FDPs manufactured with conventional lost wax, milling or DMLS fabrication methods indicated the best fit with DMLS group $(84 \pm 6 \mu \mathrm{m})$, followed by the lost wax $(133 \pm 9 \mu \mathrm{m})$ and milled group $(166 \pm 2 \mu \mathrm{m})$ [63]. However, only vertical gaps were measured and no measurements were performed in horizontal planes. In another study, where internal gaps of pre-sintered milled, cast and SLS manufactured $\mathrm{CoCr}$ metal frameworks indicated the lowest gap formation with the milled one $(32 \pm 5 \mu \mathrm{m})$, followed by SLS $(47.3 \pm 9 \mu \mathrm{m})$ and casting $(64.1 \pm 14 \mu \mathrm{m})$ [64]. Nevertheless, in this study, absolute marginal discrepancy was not measured which is in fact more of a clinical concern. In a further study, internal gaps of $60 \mathrm{CoCr}$ metal molar crowns fabricated with casting, milling or DMLS in 42 patients were measured [65]. Although overall, no statistical significant differences were found between the three systems, internal gap at the occlusal and axio-occlusal region were higher for DMLS crowns $(290.1 \pm 112 \mu \mathrm{m}$ and $188.1 \pm 69 \mu \mathrm{m}$, respectively) than for the milled $(265.7 \pm 90 \mu \mathrm{m}$ and $141.1 \pm 53 \mu \mathrm{m}$, respectively) and cast $(201.1 \pm 67 \mu \mathrm{m}$ and $140.6 \pm 48 \mu \mathrm{m})$ groups. Huang et al [66] evaluated 330 single-unit $\mathrm{CoCr}$ metal ceramic crowns in 274 patients. Each crown was randomly assigned to one of the three groups: CoCr SLM, CoCr cast and AuPt cast. The SLM Co-Cr crowns demonstrated a similar marginal fit $(75.6 \pm 32.6 \mu \mathrm{m})$ to that of the cast Au-Pt ones $(76.8 \pm 32.1 \mu \mathrm{m})$ and a better marginal fit than that of the cast Co-Cr crowns $(91 \pm 36.3 \mu \mathrm{m})$. For the internal gap however, at the occlusal region, the SLM group $(309.8 \pm 106.6 \mu \mathrm{m})$ was less accurate than the $\mathrm{CoCr}(254.6 \pm 109.6 \mu \mathrm{m})$ and $\mathrm{AuPt}(249.6 \pm 110.4 \mu \mathrm{m})$ cast groups. 


\section{Ceramic-metal adhesion}

When three-point flexural strength test results are considered, ceramic adhesion to $3 \mathrm{D}$ printed CoCr metal alloys exceeded the minimum prerequisite of $25 \mathrm{MPa}$ [65-70] required by the AINSA/ADA specification No. 38 (2000) [71] and ISO 9693:1999(E) [72]. However, although adhesion results seem to be favorable, failure types were mainly adhesive when SLS technology was used whereas conventional cast $\mathrm{CoCr}$ and $\mathrm{NiCr}$ alloys showed frequently mixed mode of cohesive failures [67-69]. This is often related to the oxide layer morphology on the surface [73], which seems to be less favorable for SLM but area fraction of adherence porcelain could be optimized with 5 to 7 times of multiple firings [74] which is less efficient but seems to increase the marginal adaptation of SLM CoCr reconstructions [75].

\section{Concluding remarks}

Additive manufacturing technologies reduce manufacturing time and costs, minimize human errors, and prevent possible defects in the cast objects compared to conventional casting methods applied for dental alloys. Currently, such technologies are more commonly used for processing $\mathrm{CoCr}$ and Titanium for dental applications. Among different technologies, available data in the dental literature accentuated more on Selective Laser Melting and Selective Laser Sintering. However, accuracy and reproducibility data do not present consist results and there appears room for improvement at 3D printed metals and ceramic interfaces and oxide layer morphologies to favour such technologies over conventional cast methods. 


\section{Conflict of Interest}

The authors declare that they have no conflict of interest. 


\section{References}

Papers of particular interest, published recently, have been highlighted as:

- Of importance

•. Of major importance

1. Singh V. Rapid prototyping, materials for RP and applications of RP. Int J Eng Res Sci. 2013;4:473-80.

2. Horn TJ, Harrysson OLA. Overview of current additive manufacturing technologies and selected applications. Sci Prog. 2012:95:255-82.

3. Van Noort R. The future of dental devices is digital. Dent Mater. 2012:28:3-12.

4. Tapie L, Lebon N, Mawussi B, et al. Understanding dental CAD/CAM for restorations. accuracy from a mechanical engineering viewpoint. Int J Comput Dent. 2015;18:343-67.

5. Strub JR, Rekow ED, Witkowski S. Computer-aided design and fabrication of dental restorations: current systems and future possibilities. J Am Dent Assoc. 2006;137:128996.

6. Beuer F, Schweiger J, Edelhoff D. Digital dentistry: an overview of recent developments for CAD/CAM generated restorations. Br Dent J. 2008;204:505-11.

7. Lebon N, Tapie L, Duret $F$, et al. Understanding dental CAD/CAM for restorations - dental milling machines from a mechanical engineering viewpoint. Part A: chairside milling machines. Int J Comput Dent. 2016;19:45-62.

8. Lebon N, Tapie L, Duret F, et al. Understanding dental CAD/CAM for restorations-dental milling machines from a mechanical engineering viewpoint. Part B: labside milling machines. Int J Comput Dent. 2016;19:115-34. 
9. Witkowski S. CAD-/CAM in dental technology. Quintessence Dent Technol. 2005;28:16984.

10. Torabi K, Farjood E, Hamedani S. Rapid prototyping technologies and their applications in prosthodontics, a review of literature. J Dent Shiraz Univ Med Sci. 2015;16:1-9.

11. ASTM, Committee F42 on Additive Manufacturing Technologies, West Conshohocken, Pa. 2009 Standard terminology for additive manufacturing - general principles and terminology. ISO/ASTM52900-15.

12. ${ }^{* *}$ Stereo Lithography Interface Specification, 3D Systems, Inc. 1988. Valencia, CA. ${ }^{* *}$ First patent on additive manufacturing technologies.

13. Deckard C, Beaman J. Process and control issues in selective laser sintering. ASME Prod Eng Div. 1988;33:191-7.

14. Deckard CR. 1986. Patent US 4863538-A. Method and apparatus for producing parts by selective sintering.

15. Mazzolini A. Selective laser sintering in biomedical engineering. Med Biol Eng Comput. 2013;51:245-56.

16. Fisher $\mathrm{P}$, Karapatis $\mathrm{N}$, Romano $\mathrm{V}$, et al. A model for the interaction of near infrared pulsed laser with metal powders in selective laser sintering. Appl Phys. A 2002;74:46774.

17. Anestiev LA, Froyen L. Model of primary rearrangement processes at liquid phase sintering and selective laser sintering due to biparticle interactions. J Appl Phys. 1997;86:4008-17.

18. Osakada K, Shiomi M. Flexible manufacturing of metallic products by selective laser melting of powder. Int J Machine Tools Manuf 2006;46:1188-93. 
19. ${ }^{* \star}$ Vandenbroucke B, Kruth JP. Selective Laser Melting of biocompatible metals for rapid manufacturing of medical parts. Rapid Prototyp J. 2007;13:196-203. **This first article investigating the possibility of producing medical or dental appliances using selective laser melting.

20. Traini $\mathrm{T}$, Mangano $\mathrm{C}$, Sammons $\mathrm{RL}$, et al. Direct laser metal sintering as a new approach to fabrication of an isoelastic functionally graded material for manufacture of porous titanium dental implants. Dent Mater. 2008;24:1525-33.

21. Horn TJ, Harrysson OLA. Overview of current additive manufacturing technologies and selected applications. Sci Prog. 2012;95:255-82.

22. *Murr LE, Gaytan SM, Ramirez DA, et al. Metal fabrication by additive manufacturing using laser and electron beam melting technologies. J Mater Sci Technol. 2012;28:1-14. ${ }^{*}$ Good technical explanation and differentiation between Selective Laser Melting and Electron Beam Melting additive manufacturing technologies.

23. **Alcisto J, Enriquez A, Garcia H, et al. Tensile properties and microstructures of laserformed Ti-6Al-4V. J Mater Eng and Performance. 2011;20:203-12. ${ }^{* *}$ In this article detailed information on microstructural characteristics and mechanical properties of Ti6Al4V are provided.

24. Abd-Elghany K, Bourrell DL. Property evaluation of 304 stainless steel fabricated by selective laser melting. Rapid Prototyp J. 2012;18:420-8.

25. Koutsoukis T, Zinelis S, Eliades G, et al. Selective laser melting technique of Co-Cr dental alloys: A review of structure and properties and comparative analysis with other available techniques. J Prosthodont. 2015;24:303-12. 
26. Vijay Venkatesh K, Vidyashree Nandini V. Direct metal laser sintering: a digitised metal casting technology. J Indian Prosthodont Soc. 2013;13:389-92.

27. AMS 4999 Specification, 2002. Titanium Alloy Laser Deposited Products 6Al-4V Annealed, SAE, Warrendale, PA.

28. Hollander DA, Von Walter $M$, Wirtz $T$, et al. Structural, mechanical and in vitro characterization of individually structured Ti-6Al-4V produced by direct laser forming. Biomater. 2006;27:955-63.

29. Niinomi M. Mechanical biocompatibilities of titanium alloys for biomedical applications. J Mech Behav Biomed Mater. 2008;1:30-42.

30. Koike M, Greer P, Owen K, et al. Evaluation of titanium alloys fabricated using rapid prototyping technologies - Electron beam melting and laser beam melting. Materials. 2011;4:1776-92.

31. International standard ISO 22674. Dentistry - Metallic materials for fixed and removable restorations and appliances. Second Edition 2016.

32. Al Jabbari YS, Koutsoukis T, Barmpagadaki $\mathrm{X}$, et al. Metallurgical and interfacial characterization of PFM Co-Cr dental alloys fabricated via casting, milling or selective laser melting. Dent Mater. 2014;30:e79-88.

33. Koutsoukis T, Zinelis S, Eliades G, et al. Selective Laser Melting technique of Co-Cr dental alloys: A review of structure and properties and comparative analysis with other available techniques. J Prosthodont. 2015;24:303-12.

34. Qian B, Saeidi K, Kvetková L, et al. Defects-tolerant Co-Cr-Mo dental alloys prepared by selective laser melting. Dent Mater. 2015;31:1435-44. 
35. Takaichi A, Suyalatu, Nakamoto T, et al. Microstructures and mechanical properties of Co-29Cr-6Mo alloy fabricated by selective laser melting process for dental applications. J Mech Behav Biomed Mater. 2013;21:67-76.

36. Kruth JP, Froyen L, Vaerenbergh JV, et al. Selective laser melting of iron-based powder. J Mater Process Technol. 2004;149:616-22.

37. Shiomi M, Osakada K, Nakamura K, et al. Residual stress within metallic model made by selective laser melting process. CIRP Annals - Manufacturing Technology. 2004;53:1958.

38. Mantrala KM, Das M, Balla VK, et al. Additive manufacturing of CoCrMo alloy: Influence of heat treatment on microstructure, tribiological, and electrochemical properties. Front Mech Eng. 2015;1:2.

39. Jevremovic D, Puskar T, Kosec B, et al. The analysis of the mechanical properties of F75 Co-Cr alloy for use in selective laser melting (SLM) manufacturing of removable partial dentures (RPD). Metalurgija. 2012;51:171-4.

40. Serra-Prat J, Cano-Batalla J, Cabratosa-Termes J, et al. Adhesion of dental porcelain to cast, milled, and laser-sintered cobalt- chromium alloys: shear bond strength and sensitivity to thermocycling. J Prosthet Dent. 2014;112:600-5.

41. Zeng L, Xiang N, Wei B. A comparison of corrosion resistance of cobalt- chromiummolybdenum metal ceramic alloy fabricated with selective laser melting and traditional processing. J Prosthet Dent 2014;112:1217-24.

42. Lu Y, Wu S, Gan $\mathrm{Y}$, et al. Investigation on the microstructure, mechanical property and corrosion behaviour of the selective laser melted CoCrW alloy for dental application. Mater Sci Eng C Mater Biol Appl. 2015;49:517-25. 
43. Donachie MJJ. Titanium - A Technical Guide. 2nd ed, 2000. P. 95-123. Materials Park, $\mathrm{OH}$ : ASM International.

44. Ding R, Guo ZX, Wilson A. Microstructural Evolution of a Ti-6Al-4V alloy During Thermo-mechanical Processing. Mater Sci Eng A. 2002;327:233-45.

45. Lütjering G, Williams JC. Titanium. 2nd Edition. 2007, p. 86-103. Springer - Verlag: Berlin.

46. Lütjering G. Influence of processing on microstructure and mechanical properties of ([alpha]+[beta]) titanium alloys. Mater Sci Eng A 1998;243:32-45.

47. Murr LE, Esquivel EV, Quinones SA, et al. Microstructures and mechanical properties of electron beam-rapid manufactured Ti-6Al-4V biomedical prototypes compared to wrought Ti-6Al-4V. Mater Char. 2009;60:96-105.

48. Williams RJ, Bibb R, Rafik T. A technique for fabricating patterns for removable partial denture frameworks using digitized casts and electronic surveying. J Prosthet Dent. 2004;91:85-8.

49. Williams RJ, Bibb R, Eggbeer D, et al. Use of CAD/CAM technology to fabricate a removable partial denture framework. J Prosthet Dent. 2006;96:96-9.

50. ${ }^{* *}$ Williams RJ, Eggbeer D, Bibb R. CAD/CAM rapid manufacturing techniques in the fabrication of removable partial denture frameworks. Quintessence J Dent Technol. 2008;6:42-50. **First dental application of additive manufacturing was described on this article for removable partial denture framework pattern.

51. Kattadiyil MT, Mursic Z, AIRumaih H, et al. Intraoral scanning of hard and soft tissues for partial removable dental prosthesis fabrication. J Prosthet Dent. 2014;112:444-8. 
52. Kanazawa M, Iwaki M, Minakuchi S, et al. Fabrication of titanium alloy frameworks for complete dentures by selective laser melting. J Prosthet Dent. 2014;112:1441-7.

53. Lin WS, Chou JC, Metz MJ, et al. Use of intraoral digital scanning for a CAD/CAMfabricated milled bar and superstructure framework for an implant-supported, removable complete dental prosthesis. J Prosthet Dent. 2015;113:509-15.

54. Lee JW, Park JM, Park EJ, et al. Accuracy of a digital removable partial denture fabricated by casting a rapid prototyped pattern: A clinical study. J Prosthet Dent. 2017 [Epub ahead of print]

55. Chan C, Haraszthy G, Geis-Gerstorfer J, et al. Scanning electron microscopic studies of the marginal fit of three esthetic crowns. Quintessence Int. 1989;20:189-93.

56. Rudd RW, Rudd KD. A review of 243 errors possible during the fabrication of a removable partial denture: part I. J Prosthet Dent. 2001;86:251-61.

57. Coli $\mathrm{P}$, Karlsson S. Fit of a new pressure-sintered zirconium dioxide coping. Int $\mathrm{J}$ Prosthodont. 2004;17:59-64.

58. Quante K, Ludwig K, Kern M. Marginal and internal fit of metal-ceramic crowns fabricated with a new laser melting technology. Dent Mater. 2008;24:1311-5.

59. Ucar Y, Akova T, Akyil MS, et al. Internal fit evaluation of crowns prepared using a new dental crown fabrication technique: laser-sintered Co-Cr crowns. J Prosthet Dent. 2009;102:253-9.

60. Xu D, Xiang N, Wei B. The marginal fit of selective laser melting-fabricated metal crowns: an in vitro study. J Prosthet Dent. 2014;112:1437-40.

61. Huang Z, Zhang L, Zhu J, et al. Clinical Marginal and Internal Fit of Crowns Fabricated Using Different CAD/CAM Technologies. J Prosthodont. 2015;24:291-5. 
62. Huang Z, Zhang L, Zhu J, et al. Clinical marginal and internal fit of metal ceramic crowns fabricated with a selective laser melting technology. J Prosthet Dent. 2015;113:623-7.

63. Örtorp A, Jönsson D, Mouhsen A, et al. The fit of cobalt-chromium three-unit fixed dental prostheses fabricated with four different techniques: A comparative in vitro study. Dent Mater. 2011;27:356-63.

64. Kim KB, Kim JH, Kim WC, et al. Three-dimensional evaluation of gaps associated with fixed dental prostheses fabricated with new technologies. J Prosthet Dent. 2014;112:1432-6.

65. Tamac E, Toksavul S, Toman M. Clinical marginal and internal adaptation of CAD/CAM milling, laser sintering, and cast metal ceramic crowns. J Prosthet Dent. 2014;112:90913.

66. Huang Z, Zhang, Zhu J, et al. Clinical marginal and internal fit of metal ceramic crowns fabricated with a selective laser melting technology. J Prosthet Dent. 2015;113:623-7.

67. Akova T, Ucar Y, Tukay A, et al. Comparison of the bond strength of laser-sintered and cast base metal dental alloys to porcelain. Dent Mater. 2008;24:1400-04.

68. Xiang N, Xin XZ, Chen J, et al. Metal-ceramic bond strength of Co-Cr alloy fabricated by selective laser melting. J Dent .2012;40:453-7.

69. Wu L, Zhu H, Gai X, et al. Evaluation of the mechanical properties and porcelain bond strength of cobalt-chromium dental alloy fabricated by selective laser melting. J Prosthet Dent. 2014;111:51-5.

70. Wang $\mathrm{H}$, Feng $\mathrm{Q}$, Li N, et al. Evaluation of metal-ceramic bond characteristics of three dental Co-Cr alloys prepared with different fabrication techniques. J Prosthet Dent. 2016;116:916-23. 
71. AINSA/ADA. Standard No. 38-Metal-Ceramic Dental Restorative Systems: 2000 (Reaffirmed 2015). Geneva. Switzerland.

72. ISO 9693:1999(E) Metal ceramic dental restorative systems. Geneva, Switzerland.

73. Li J, Chen C, Liao J, et al. Bond strengths of porcelain to cobalt-chromium alloys made by casting, milling, and selective laser melting. J Prosthet Dent. 2016 [Epub ahead of print].

74. Ren XW, Leng L, Wei ZM, et al. Effects of multiple firings on metal-ceramic bond strength of Co- $\mathrm{Cr}$ alloy fabricated by selective laser melting. J Prosthet Dent. 2016;115:109-14.

75. Zheng L, Zhang Y, Liu Z, et al. Effects of repeated firing on the marginal accuracy of CoCr copings fabricated by selective laser melting. J Prosthet Dent. 2015;113:135-9. 
Table 1. Brands and chemical composition of $\mathrm{CoCr}$ alloys provided for additive manufacturing.

\begin{tabular}{|c|c|c|}
\hline \multirow{2}{*}{$\begin{array}{l}\text { Brand } \\
\text { EOS CoCr MP1 }\end{array}$} & \multicolumn{2}{|c|}{ Chemical Composition (wt\%) } \\
\hline & $\begin{array}{l}\text { Co: } 60-65 \\
\text { Cr: } 26-30 \\
\text { Mo: } 5-7 \\
\text { Si } \leq 1\end{array}$ & $\begin{array}{l}\mathrm{Fe} \leq 0.75 \\
\mathrm{Mn} \leq 1 \\
\mathrm{C} \leq 0.16 \\
\mathrm{Ni} \leq 0.1\end{array}$ \\
\hline EOS CoCr SP2 & $\begin{array}{l}\text { Co: } 63.8 \\
\text { Cr: } 24.7 \\
\text { Mo: } 5.1 \\
\text { W: } 5.4 \\
\text { Si: } 1\end{array}$ & $\begin{array}{l}\mathrm{Fe}<0.75 \\
\mathrm{Mn}<0.1\end{array}$ \\
\hline Renishaw CoCr DG1 & $\begin{array}{l}\text { Co: } 63.9 \\
\text { Cr: } 24.7 \\
\text { Mo: } 5 \\
\mathrm{Ni}<0.5 \\
\mathrm{~N}<0.25\end{array}$ & $\begin{array}{l}\mathrm{Fe}<0.5 \\
\mathrm{Mn}<1 \\
\mathrm{Al}<0.10 \\
0<0.10 \\
\mathrm{C}<0.05\end{array}$ \\
\hline $\begin{array}{l}\text { SLM Solutions } \\
\text { CoCr28Mo6 acc to ASTM F75 }\end{array}$ & $\begin{array}{l}\text { Co: Balance } \\
\text { Cr: } 27-30 \\
\text { Mo: } 5-7 \\
\text { W: } 0.20 \\
\text { Si: } 1\end{array}$ & $\begin{array}{l}\text { Al: } 0.10 \\
\text { Fe: } 0.75 \\
\text { Mn: } 1 \\
\text { C: } 0.35 \\
\text { N: } 0.25 \\
\text { B, S: } 0.01\end{array}$ \\
\hline $\begin{array}{l}\text { SLM Solutions } \\
\text { MediDent }\end{array}$ & $\begin{array}{l}\text { Co: Balance } \\
\text { Cr: } 22.7-26.7 \\
\text { Mo: } 4-6 \\
\text { W: } 4.4-6.4 \\
\text { Si: } 2\end{array}$ & $\begin{array}{l}\text { Fe: } 0.5 \\
\text { Mn: } 0.10 \\
\text { C: } 0.02 \\
\text { Ni: } 0.10 \\
\text { B, S: } 0.10\end{array}$ \\
\hline $\begin{array}{l}\text { 3D systems LayerWise } \\
\text { CoCr ASTM F75 }\end{array}$ & $\begin{array}{l}\text { Co: Balance } \\
\text { Cr: } 27-30 \\
\text { Mo: } 5-7 \\
\text { W } \leq 0.2 \\
\text { Si } \leq 1\end{array}$ & $\begin{array}{l}\mathrm{Fe} \leq 0.75 \\
\mathrm{Mn} \leq 1 \\
\mathrm{C} \leq 0.35 \\
\mathrm{Ni} \leq 0.5 \\
\mathrm{~B}, \mathrm{~S} \leq 0.01 \\
\mathrm{P} \leq 0.02 \\
\mathrm{Al}, \mathrm{Ti} \leq 0.1 \\
\mathrm{~N} \leq 0.25\end{array}$ \\
\hline $\begin{array}{l}\text { 3D Systems LayerWise } \\
\text { CoCr 3DS Dentwise }\end{array}$ & $\begin{array}{l}\text { Co: } 59 \\
\text { Cr: } 25 \\
\text { W: } 9.5 \\
\text { Mo: } 3.5 \\
\text { Si: } 1\end{array}$ & $\mathrm{C}, \mathrm{Fe}, \mathrm{Mn}, \mathrm{N}:<1.5$ \\
\hline $\begin{array}{l}\text { Concept Laser } \\
\text { Remanium star CL }\end{array}$ & $\begin{array}{l}\text { Co: } 60.5 \\
\text { Cr: } 28 \\
\text { W: } 9 \\
\text { Si: } 1.5\end{array}$ & $\begin{array}{l}\mathrm{Fe}, \mathrm{Mn} \mathrm{N}, \mathrm{Nb} \text { and free } \\
\text { form } \mathrm{Ni}, \mathrm{Be}, \mathrm{Ga}<1\end{array}$ \\
\hline BEGO & $\begin{array}{l}\text { Co: } 63.9 \\
\text { Cr: } 24.7 \\
\text { W: } 5.4 \\
\text { Mo: } 5.0 \\
\text { Si } \leq 1\end{array}$ & \\
\hline
\end{tabular}




\begin{tabular}{|c|c|c|c|c|c|c|c|c|c|}
\hline Property & EOS MP1 & EOS SP2 & Renishaw & $\begin{array}{l}\text { SLM Solutions } \\
\text { CoCr28Mo6 }\end{array}$ & $\begin{array}{l}\text { SLM Solutions } \\
\text { MediDent }\end{array}$ & $\begin{array}{l}\text { Concept Laser } \\
\text { Remanium star CL }\end{array}$ & $\begin{array}{l}\text { 3D systems } \\
\text { ASTM F75 }\end{array}$ & $\begin{array}{l}\text { 3D Systems } \\
\text { 3DS Dentwise }\end{array}$ & BEGO \\
\hline Alloy type ISO 22674 & 4 & 4 & 4 & 4 & 4 & 5 & 5 & 4 & 5 \\
\hline Density $\left(\mathrm{g} / \mathrm{cm}^{3}\right)$ & 8.3 & 8.5 & 8.5 & NA & NA & 8.6 & 8.35 & 8.8 & 8.5 \\
\hline Tensile strength (MPa) & 1100 & 1350 & $1097-1104$ & $1101-1039$ & 1062 & 1030 & 1000 & 910 & $1150-1400$ \\
\hline Yield strength (MPa) & 600 & 850 & $683-714$ & $720-705$ & 319 & 635 & 650 & 650 & $790-1000$ \\
\hline Elongation at break (\%) & 20 & 3 & $16-21$ & 10 & NA & 10 & 20 & 8 & 9 \\
\hline Young's modulus (GPa) & 200 & 200 & 220 & 194-191 & 114 & 230 & 230 & 200 & 210 \\
\hline Hardness (HV) & $350-450$ & 420 & $400-412$ & $375-372$ & NA & NA & 400 & 310 & 360 \\
\hline $\begin{array}{l}\text { Coefficient thermal } \\
\text { Expansion }\left({ }^{\circ} \mathrm{C}\right)\end{array}$ & $13.6 \times 10^{-6}$ & $14.5 \times 10^{-6}$ & $10.2 \times 10^{-6}$ & NA & NA & $14.1 \times 10^{-6} /{ }^{\circ} \mathrm{C}$ & $14.3 \times 10^{-6} /{ }^{\circ} \mathrm{C}$ & $14.0 \times 10^{-6} /{ }^{\circ} \mathrm{C}$ & $14.1 \times 10^{-6} /{ }^{\circ} \mathrm{C}$ \\
\hline Melting interval $\left({ }^{\circ} \mathrm{C}\right)$ & $1350-1430$ & $1410-1450$ & $1260-1482$ & NA & NA & $1320-1420$ & $1350-1430$ & $1305-1400$ & $1370-1420$ \\
\hline
\end{tabular}

Table 2. Physical and mechanical properties of 3D printed $\mathrm{CoCr}$ (after stress relief) provided by their manufacturers. 


\begin{tabular}{|c|c|c|}
\hline Brand & Compositio & \\
\hline $\begin{array}{l}\text { EOS DMLS } \\
\text { Ti64ELI }\end{array}$ & $\begin{array}{l}\text { Ti: Balance } \\
\text { Al: } 5.5-6.5 \\
\text { V: } 3.5-4.5 \\
O<0.110\end{array}$ & $\begin{array}{l}N<0.04 \\
C<0.08 \\
H<0.012 \\
F e<0.250 \\
Y<0.005\end{array}$ \\
\hline $\begin{array}{l}\text { Renishaw } \\
\text { Ti6Al4V ELI-0406 }\end{array}$ & $\begin{array}{l}\text { Ti: Balance } \\
\text { Al: } 5.5-6.75 \\
\text { V: } 3.5-4.5 \\
O<0.2\end{array}$ & $\begin{array}{l}\mathrm{N}<0.05 \\
\mathrm{C}<0.08 \\
\mathrm{H}<0.015 \\
\mathrm{Fe}<0.3\end{array}$ \\
\hline $\begin{array}{l}\text { SLM Solutions } \\
\text { Ti6Al4V ELI }\end{array}$ & $\begin{array}{l}\text { Ti: Balance } \\
\text { Al: } 5.5-6.5 \\
\text { V: } 3.5-4.5\end{array}$ & $\begin{array}{l}\text { Fe: } 0.25 \\
\mathrm{C}: 0.08 \\
\mathrm{~N}: 0.03 \\
\mathrm{O}: 0.13 \\
\mathrm{H}: 0.0125\end{array}$ \\
\hline $\begin{array}{l}\text { Concept Laser } \\
\text { Rematitan }\end{array}$ & $\begin{array}{l}\text { Ti: } 90 \\
\text { Al: } 6 \\
\text { V: } 4\end{array}$ & $\begin{array}{l}\mathrm{N}, \mathrm{C}, \mathrm{H}, \mathrm{Fe} \text { and } \\
\mathrm{O}<1\end{array}$ \\
\hline $\begin{array}{l}\text { 3D systems } \\
\text { LaserForm Ti Grade } 23\end{array}$ & $\begin{array}{l}\text { Ti: Balance } \\
\text { Al: } 5.5-6.5 \\
\text { V: } 3.5-4.5 \\
O \leq 0.13\end{array}$ & $\begin{array}{l}\mathrm{N}<0.03 \\
\mathrm{C}<0.08 \\
\mathrm{H} \leq 0.012 \\
\mathrm{Fe}<0.25 \\
\mathrm{Y} \leq 0.005\end{array}$ \\
\hline $\begin{array}{l}\text { Arcam EBM } \\
\text { Ti6Al4V ELI }\end{array}$ & $\begin{array}{l}\text { Ti: Balance } \\
\text { Al: } 5.5-6-5 \\
\text { V: } 3.4-4.5 \\
\text { O<0.13 }\end{array}$ & $\begin{array}{l}\mathrm{N}<0.05 \\
\mathrm{C}<0.08 \\
\mathrm{H}<0.012 \\
\mathrm{Fe}<0.25\end{array}$ \\
\hline
\end{tabular}

Table 3. Brands and chemical composition of Ti alloys provided for additive manufacturing. 


\begin{tabular}{|l|l|l|l|l|l|l|}
\hline Property & EOS Ti64ELI & Renishaw & $\begin{array}{l}\text { SLM Solutions } \\
\text { Ti6AI4V ELI }\end{array}$ & $\begin{array}{l}\text { Concept Laser } \\
\text { Rematitan }\end{array}$ & 3D systems & ARCAM EBM \\
\hline Grade/type & NA & 23 & 23 & 4 & 23 & 5 \\
\hline Density $\left(\mathrm{g} / \mathrm{cm}^{3}\right)$ & 4.41 & 4.42 & NA & 4.5 & 4.42 & NA \\
\hline Tensile strength (MPa) & 1070 & 1089 & 1286 & 1005 & 940 & 860 \\
\hline Yield strength (MPa) & 1010 & 1007 & 1116 & 950 & 850 & 795 \\
\hline Elongation at break (\%) & 14 & 14 & 8 & 10 & 15 & 10 \\
\hline Young's modulus $(\mathrm{GPa})$ & NA & 129 & 111 & 115 & $105-120$ & 114 \\
\hline Hardness $(\mathrm{HV})$ & 34 & 38 & 38 & NA & 30 & NA \\
\hline Coefficient thermal expansion & NA & $8-9 \times 10^{-6 /}{ }^{\circ} \mathrm{C}$ & NA & $10.16 \times 10^{-6 /}{ }^{\circ} \mathrm{C}$ & $9.7 \times 10^{-6 /}{ }^{\circ} \mathrm{C}$ & NA \\
\hline Melting interval ( $\left.{ }^{\circ} \mathrm{C}\right)$ & NA & $1635-1665$ & NA & $1604-1655$ & $1692-1698$ & NA \\
\hline
\end{tabular}

Table 4. Physical and mechanical properties of 3D printed Ti alloys provided by their manufacturers. NA: Not available. 


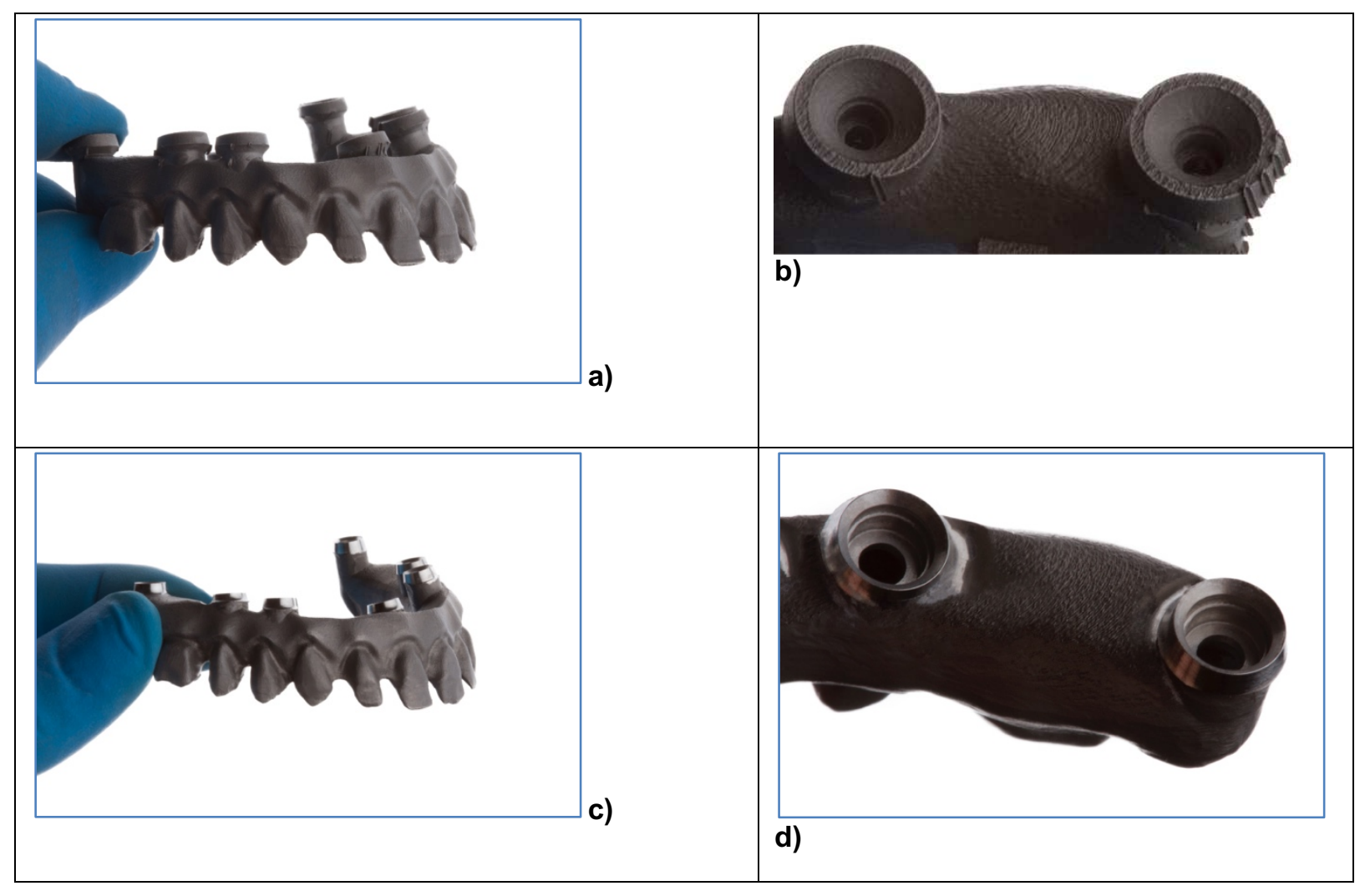

Figs. 1a-d. a) SLM additive manufactured Complete maxillary CoCr implant framework, b) detailed photo of texture of the 3D printed framework, c) final implant framework and d) detailed aspect after the milled implant interface. 